\title{
DESIGN AND FABRICATION OF PORTABLE ATMOSPHERIC WATER SEQUESTRATOR AS AN OFF-GRID WATER SYSTEM
}

\author{
Lorenz E. Borromeo 1 \\ ${ }^{1}$ Researcher, Department of Chemical Engineering, Bicol University - Legazpi City, \\ Philippines
}

Article DOI: $\underline{\text { https://doi.org/10.36713/epra4745 }}$

\begin{abstract}
The lack of access to clean water has been one of the major issues in water-stressed countries. In this study, the design and fabrication of a prototype portable atmospheric water sequestrator device was carried out and tested for its ability to harness available water vapor in the atmosphere. The system utilized the concept of Peltier effect in Peltier units as a new way to liquefy atmospheric water. MATLAB® was used to investigate effects of different parameters namely humidity ratio, volumetric air flow rate, and Peltier surface temperature on water generation. Results showed that humidity ratio exhibited the highest significance among the parameters. Furthermore, the highest water production was found to be $7.643 \mathrm{~mL}$ at a Peltier surface temperature of $4{ }^{\circ} \mathrm{C}$, air flowrate of $24 \mathrm{ft}^{3} / \mathrm{min}$, and humidity ratio of 0.021 . Moreover, the physicochemical characteristics of the water produced was well under the Philippine standards and can be classified into Public Water Supply Class I.
\end{abstract}

KEYWORDS: Design and fabrication, portable water sequestrator, Peltier effect, water generation

\section{INTRODUCTION}

The current need for clean water has been one of the major issues that must be addressed not only in the water-stressed countries, but also in the entire world. According to the recent statistical records provided by United Nations Educational, Scientific, and Cultural Organization (UNESCO), at least 663 million people across the globe still do not have access to clean and safe water ${ }^{[1]}$. In the Philippines, the same issue is being experienced by those situated in rural areas, thus resulting to around 6,000 deaths per year caused by water-borne diseases found in poor water quality. Hence, searching out ways to obtain clean water easily are some of the most vital international dialogues as these can change the lives of millions of people especially those situated in poor countries.

Water can be harnessed from different sources such as surface water, ground water, or seawater. However, the presence of enormous number of contaminants requires stringent water treatment, which utilizes treatment chemicals, to meet existing water standards. The widespread use of these treatment chemicals may potentially cause hazardous side effects if taken in excess ${ }^{[2]}$. Moreover, the increasing number of water filtration stations in the Philippines has taken the advantage of extracting groundwater and processing it to become clean and potable. A major drawback of these water stations is the bulky and huge equipment on which these facilities operate with, thus entailing difficulty in transporting into less accessible places where the need is great ${ }^{[3]}$.

Developing new ways of harnessing clean water, aside from those conventional ones, without harming the public health and environment have been of great interest. Tapping another hidden reservoir of water, which is the atmosphere, is one of the compelling ways in the new era[ ${ }^{[4]}$. With the enormous water volume it contains, harnessing it is of a significant way to further improve the status of clean water worldwide.

In this work, a prototype portable atmospheric water sequestrator (PAWS) was designed and fabricated. Peltier units were integrated in the system as an alternative cooling technology and investigated 


\section{EPRA International Journal of Research and Development (IJRD) \\ Volume: 5 | Issue: 7 | July 2020 \\ - Peer Reviewed Journal}

its capability to transform available atmospheric water vapor to a liquified form. The effects of different parameters namely on-site humidity ratios, volumetric air flow rates, and Peltier surface temperatures on water production were investigated. Moreover, primary physico - chemical parameters namely total dissolved solids (TDS), turbidity, color, odor, $\mathrm{pH}$, total hardness, and chloride concentration were used to characterize the water generated by
PAWS and compared it with existing water standards in the Philippines.

\section{METHODOLOGY}

\subsection{Materials}

All materials used for fabrication were locally sourced in the Philippines. The list of materials is shown in Table 1.

Table 1. List of Materials for the Fabrication of PAWS

\begin{tabular}{|c|c|}
\hline Materials & Pieces \\
\hline TEC -12706 Peltier Units $(4 \times 4 \mathrm{~cm})$ & 4 \\
\hline Aluminum Heat Sinks (4.5 x 5 in) & 1 \\
\hline Potentiometers & 2 \\
\hline Water Pump (4 L/min) & 1 \\
\hline Air Fan (80 mm) & 4 \\
\hline Aluminum Sheets (1 x 1 m) & 1 \\
\hline Copper Tubing (3/8 in.) & 1 \\
\hline Plastic (Tygon) Tubing & 1 \\
\hline High-Temperature Sealant & 1 \\
\hline High-Grade Thermal Paste & 2 \\
\hline
\end{tabular}

\subsection{Design Considerations}

\subsubsection{Design of Air Fan Heat Exchanger} System

A rough scale down was implemented during construction of the air fan heat exchanger system. The study of Kadhim and his colleagues in 2016 was used as the design basis ${ }^{[5]}$. A $150 \mathrm{~mm} \times 150 \mathrm{~mm}$ air fan heat exchanger with 8 tube passes was fabricated using smooth copper tubes. Modification on the last four passes were carried out in window positions relative to the last four passes to maintain portability and increase air and coolant turbulent flow formation.

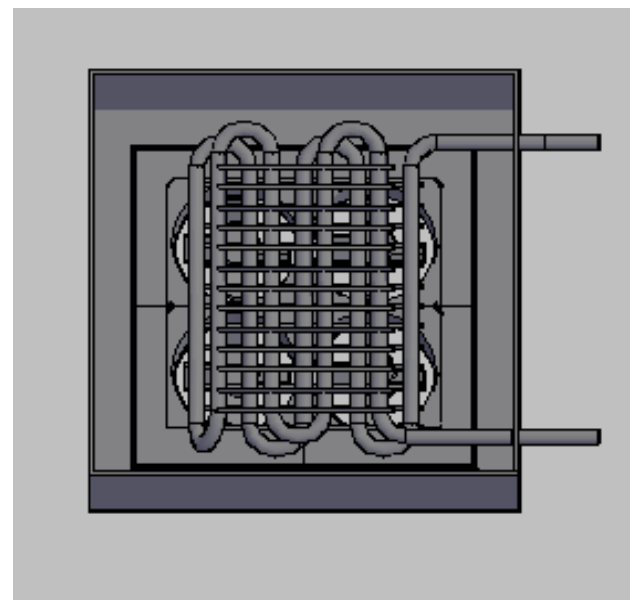

Figure 1. Front view of the air fan heat exchanger system of PAWS

\subsubsection{Design of Coolant Tank}

The coolant tank was designed to have an overall dimension of $127 \mathrm{~mm} \times 127 \mathrm{~mm} \times 51 \mathrm{~mm}$. A heat sink of dimension $127 \mathrm{~mm} \times 127 \mathrm{~mm} \times 25 \mathrm{~mm}$ was attached inside the coolant tank to easily dissipate the heat coming from the attached Peltier units into the coolant water. Two holes fitted with copper tubing were made to accommodate the circulation of the coolant water from the tank to the heat exchanger. 


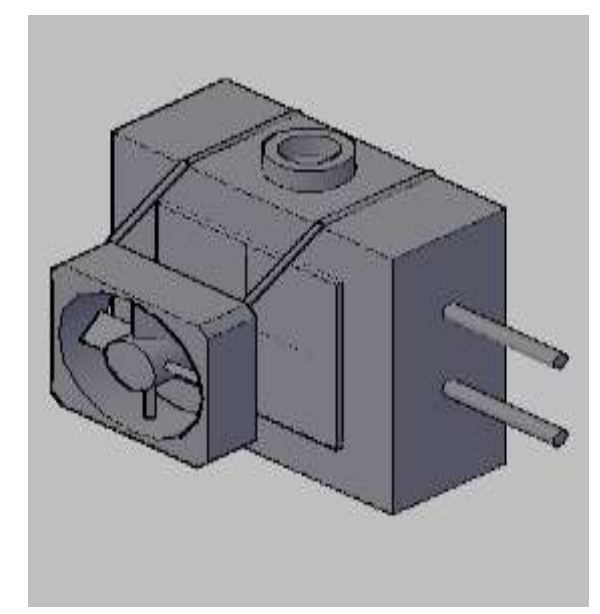

Figure 2. Coolant tank design of PAWS

\subsubsection{Full Set-Up}

The overall set - up consisted of two (2) main parts; the coolant tank on which Peltier units were attached and the air fan heat exchanger system. The Peltier units were attached to the exposed area of the heat sink in the coolant tank. Meanwhile, an $80 \mathrm{~mm}$ fan was installed in front to blow air directly on the Peltier units. Both the coolant tank and the heat exchanger system were connected using plastic tubing to direct the circulation of the coolant water from the coolant tank to the air fan heat exchanger and vice versa. The coolant was recirculated from the tank to the heat exchanger with the use of a mini direct current (DC) water pump. The water generated on the Peltier's surfaces was collected using a drip tray situated underneath the Peltier units.

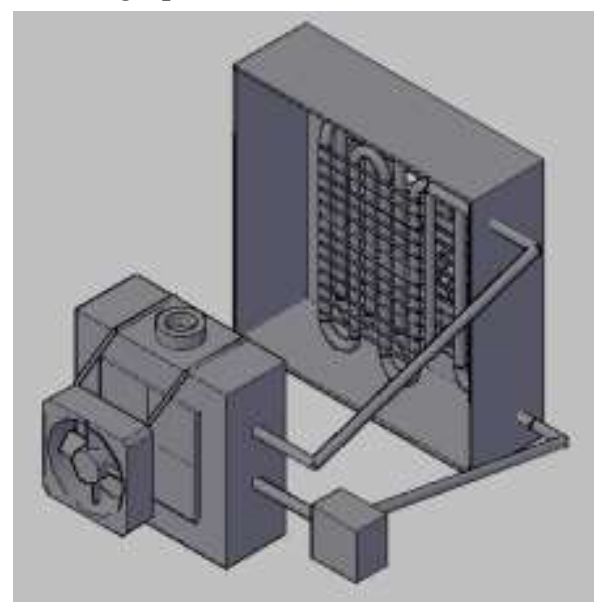

Figure 3. Full Set-Up of Portable Atmospheric Water Sequestrator

\subsection{Experimental Runs}

The device was operated on different days at different times to achieve desired relative humidity and temperature conditions. A sensitive hygrometer was used to measure the actual relative humidity and temperature of the surroundings. For the modifications of the volumetric air flow rate, the blade speed of the fan in front of the Peltier units was adjusted based from the entering current. A $500 \mathrm{ohm}$ potentiometer was used to regulate the current flow of the fan. The same principle was followed for the regulation of the cold facial temperature of the Peltier units using a $5000 \mathrm{ohm}$ potentiometer.

Each experimental run was operated for 3 hours in a collection elevation of $1 \mathrm{~m}$ above ground. The constant electrical supply was provided by a $12 \mathrm{~A}$ AC - DC converter. A separate converter was used for the regulation of the blade speed of the fan in front of the Peltier units. The entire batch experimentation ran for 57 hours.

The investigation of the performance of the device to harness water vapor was carried out using 


\section{EPRA International Journal of Research and Development (IJRD) \\ Volume: 5 | Issue: 7 | July 2020 \\ - Peer Reviewed Journal}

predetermined values of on-site humidity ratio $(0.017$ $\mathrm{kg}$ water $/ \mathrm{kg}$ dry air, $0.019 \mathrm{~kg}$ water $/ \mathrm{kg}$ dry air, 0.021 $\mathrm{kg}$ water $/ \mathrm{kg}$ dry air), volumetric air flow rate $(10$ $\left.\mathrm{ft}^{3} / \mathrm{min}, 17 \mathrm{ft}^{3} / \mathrm{min}, 24 \mathrm{ft}^{3} / \mathrm{min}\right)$, and Peltier surface temperature $\left(4{ }^{\circ} \mathrm{C}, 12{ }^{\circ} \mathrm{C}, 20^{\circ} \mathrm{C}\right)$. Experiments were performed with total of 19 runs with parameter values generated through response surface methodology (RSM) by MATLAB $\AA$.

\subsection{Physico - Chemical Analyses}

The physical and chemical characterization of the condensate collected from the atmospheric water sequestrator was carried out to classify its quality based from the standards set by the Philippine
National Standards in Drinking Water (PNSDW). Samples were sent to Metropolitan Naga Water District, an accredited water testing center in Naga City, Philippines, to quantify values of $\mathrm{pH}$, color, odor, total dissolved solids (TDS), turbidity, chloride, and total hardness $\left(\right.$ as $\left.\mathrm{CaCO}_{3}\right)$ concentrations.

\section{RESULTS AND DISCUSSION}

\subsection{Water Generation}

Operating conditions generated by MATLAB $\AA$ were followed to quantify the water generated by PAWS. The water generation response of PAWS is shown in Table 2.

Table 2. Water Generation Response of PAWS

\begin{tabular}{|c|c|c|c|c|}
\hline Runs & $\begin{array}{l}H^{a} \\
\text { (A) }\end{array}$ & $\begin{array}{l}A F^{b} \\
\text { (B) }\end{array}$ & $\begin{array}{c}\text { PST }^{c} \\
\text { (C) }\end{array}$ & Generation $^{\mathrm{d}}$ \\
\hline 1 & 0.019 & 17 & 12 & 6.5 \\
\hline 2 & 0.019 & 17 & 12 & 6.8 \\
\hline 3 & 0.019 & 17 & 12 & 6.6 \\
\hline 4 & 0.019 & 17 & 12 & 6.6 \\
\hline 5 & 0.019 & 17 & 12 & 6.4 \\
\hline 6 & 0.017 & 10 & 4 & 5.5 \\
\hline 7 & 0.021 & 10 & 4 & 6.8 \\
\hline 8 & 0.017 & 24 & 4 & 5.9 \\
\hline 9 & 0.021 & 24 & 4 & 7.6 \\
\hline 10 & 0.017 & 10 & 20 & 5.6 \\
\hline 11 & 0.021 & 10 & 20 & 6.6 \\
\hline 12 & 0.017 & 24 & 20 & 5.6 \\
\hline 13 & 0.021 & 24 & 20 & 6.7 \\
\hline 14 & 0.017 & 17 & 12 & 5.7 \\
\hline 15 & 0.021 & 17 & 12 & 7.5 \\
\hline 16 & 0.019 & 10 & 12 & 6.3 \\
\hline 17 & 0.019 & 24 & 12 & 6.7 \\
\hline 18 & 0.019 & 17 & 4 & 6.8 \\
\hline 19 & 0.019 & 17 & 20 & 6.4 \\
\hline & & & & 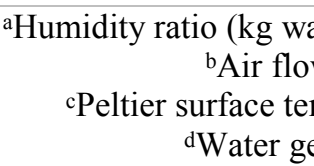 \\
\hline
\end{tabular}

The mathematical correlation among the operating parameters can be represented by the model equation below

Water generated $=-8.5961+0.18173 \mathrm{C}+0.089463 \mathrm{~B}+1053.74 \mathrm{~A}-2.46 \times 10^{-3} \mathrm{CB}-$ $7.03125 \mathrm{CA}+4.46429 \mathrm{BA}-1.15 \times 10^{-3} \mathrm{C}^{2}-3.55 \times 10^{-3} \mathrm{~B}^{2}-18427.8 \mathrm{~A}^{2}$

Where $\mathrm{A}$ is the humidity ratio $(\mathrm{kg}$ water $/ \mathrm{kg} \mathrm{da}), \mathrm{B}$ is the air flowrate $\left(\mathrm{ft}^{3} / \mathrm{min}\right)$, and $\mathrm{C}$ is the Peltier surface temperature $\left({ }^{\circ} \mathrm{C}\right)$. 


\subsection{Optimal Operating Condition}

Using Design Expert $\AA$, the optimal conditions on which PAWS can be operated was determined. A set of randomized runs were done to effectively point out the highest water produced based on the model generated. The results are shown in Table 3.

The air flow rate must be operated at $24 \mathrm{ft}^{3} / \mathrm{min}$, at a humidity ratio of 0.021 while maintaining a surface temperature of $4{ }^{\circ} \mathrm{C}$. The maximum volume of water recorded at this condition was $7.643 \mathrm{~mL}$.

Table 3. Optimum Parametric Values for Water Generation

\begin{tabular}{|c|c|c|c|}
\hline $\begin{array}{c}\mathbf{H R}^{\mathrm{a}} \\
\text { (A) }\end{array}$ & $\begin{array}{c}\mathbf{A F}^{\mathrm{b}} \\
\text { (B) }\end{array}$ & $\begin{array}{c}\text { PST }^{\mathrm{c}} \\
\text { (C) }\end{array}$ & Generation $^{\mathrm{d}}$ \\
\hline 0.021 & 24 & 4 & 7.643 \\
\hline
\end{tabular}

\subsection{Physico-chemical Characterization}

The results of the physico-chemical characterization were shown in Table 4 . The values

were compared to the existing drinking water standards set by Philippine National Standards for Drinking Water (PNSDW).

Table 4. Physico-chemical Characteristics of the Water Generated by PAWS

\begin{tabular}{|c|c|c|c|}
\hline Parameter & Unit & Tested & PNSDW \\
\hline $\begin{array}{c}\text { Total Dissolved Solids } \\
\text { (TDS) }\end{array}$ & $\mathrm{mg} / \mathrm{L}$ & 42.2 & 500 \\
\hline Turbidity & NTU & 0.43 & 5 \\
\hline $\begin{array}{c}\text { Power of Hydrogen } \\
(\mathrm{pH})\end{array}$ & - & 7.7 & $6.5-8.5$ \\
\hline $\begin{array}{c}\text { Chloride } \\
\text { Concentration }\end{array}$ & $\mathrm{mg} / \mathrm{L}$ & 34.5 & 250 \\
\hline Color & TCU & $1 \mathrm{TCU}$ & True; 5 Color Units \\
\hline Odor & - & Unobjectionable & $\begin{array}{l}\text { No objectionable } \\
\text { Odor }\end{array}$ \\
\hline $\begin{array}{l}\text { Total Hardness } \\
\left(\mathrm{CaCO}_{3}\right) \\
\text { Concentration }\end{array}$ & $\mathrm{mg} / \mathrm{L}$ & 19 & 300 \\
\hline
\end{tabular}

\subsubsection{Total Dissolved Solids}

The total dissolved solids (TDS) refer to all ions dissolved in water. The composition of which is mainly inorganic salts and some small amounts of organic matter that are dissolved in water. The resulting TDS concentration was measured at 42.2 $\mathrm{mg} / \mathrm{L}$, well within than the PNSDW standards. This could be explained by the natural chemical composition of the air which is mainly affected by human activities. Pollutants found in air could be traced from fuel combustion of automobiles and anthropogenic activities on a daily basis. These emitted pollutants are transported by winds. In highly populated cities (urban), these compounds are thoroughly distributed in the air ${ }^{[6]}$. Indoor air pollutants could be sourced from plant and animal bioaerosols and minerals, combustion, and home or personal care aerosols. These can be produced indoors or enter the house through openings ${ }^{[7]}$.

\subsubsection{Turbidity}

Turbidity is a measure of the amount of light that is being scattered by particulates present in water. These particulates include divided inorganic and organic matter, soluble colored organic compounds, and other microscopic organisms. Some of the particles which causes turbidity are from the particlemicroorganism complexes. The microorganisms of concern include pathogenic protozoa and bacteria which are commonly found in atmospheric water ${ }^{[8]}$.

Based from the cited sources, the turbidity in the harnessed water is due to the presence of fecal coliforms, total coliforms, and other dissolved ions. These microorganisms form matrix on smaller particles or ions present in the water causing the light 


\section{SJIF Impact Factor: 7.001| ISI I.F.Value:1.241| Journal DOI: 10.36713/epra2016 \\ ISSN: 2455-7838(Online) EPRA International Journal of Research and Development (IJRD)}

to be scattered. However, the value indicated above is still way below the PNSDW.

\subsubsection{Power of Hydrogen}

The $\mathrm{pH}$ is a measure of the total hydrogen ion species in the water sample. The water tested has a $\mathrm{pH}$ result of 7.7 in line with the acceptable value of 6.5-8.5. A slight increase of 0.7 was due to the dissolved ions which forms acidic or basic complexes as mentioned in the study by Hoff. Although present in minute quantities, these complexes could alter the overall hydrogen ion concentration and therefore affects the $\mathrm{pH}$.

\subsubsection{Chloride}

The mere presence of chlorides in the tested water could be attributed to the airborne chlorides found near coastal regions. The intrusion of chloride into the atmosphere is usually caused by wind-borne sprays of rain. The concentration of chloride in air decreases as increasing the distance from the shore. Under heavily industrialized areas, the amount of chloride ion in the atmosphere also increases due to coal burning. Thus, the presence of chlorine in Legazpi City is fairly because it is geographically a coastal city[9].

\subsubsection{Color and Odor}

The discoloration of the water could be attributed to different dissolved metal ions that are present in excess. Blue water can result if there is an overloading of copper or lead into the water, black or dark brown water if manganese ions are in excess, and reddish if iron ions are present excessively. Meanwhile, the odor coming from the water is traced from organic sources that are volatile ${ }^{[10]}$.

The result obtained a value of 1 TCU, an acceptable value below the limit of 5 TCU for its color evaluation. The ions dissolved were not in excess to cause discoloration of the water sample. In addition, the water sample has an unobjectionable odor, thus no traces of volatile organic pollutants, that may cause odor problems, were detected.

\subsubsection{Total Hardness}

The abundance of carbonate rich rocks such as calcite on the surface could probably weather and be dissolved in water and be vaporized. It could also take form as mineral dust that may be constantly carried by the circulating air. It is therefore possible that carbonates may interact and mix with atmospheric water and be present in small amount in the water collected during experimentation ${ }^{[11]}$.

\section{CONCLUSION}

A working portable atmospheric water sequestrator (PAWS) was constructed and tested for its ability to condense atmospheric water vapor to clean water. The physico - chemical characteristics of the water generated could be classified as Public Water Supply Class I. The fabrication of such could be an alternative way to harness usable water easily and conveniently.

\section{Conflict of Interest}

None.

\section{REFERENCES}

1. Rose, J.B., Water, sanitation and the millennium development goals: A report card on global progress. Water quality and health, 2015: p. 1-2.

2. Simate, G.S., et al., Human health effects of residual carbon nanotubes and traditional water treatment chemicals in drinking water. Environment international, 2012. 39(1): p. 38-49.

3. Cabacungan, P.M., CLEAN WATER SYSTEMS USING SOLAR POWER FOR OFF-GRID COMMUNITIES. 2009, Ateneo de Manila University.

4. Nandy, A., et al., A project on atmospheric water generator with the concept of peltier effect. International Journal of Advanced Computer Research, 2014. 4(2): p. 481.

5. Kadhim, Z.K., M.S. Kassim, and A.Y.A. Hassan, CFD study for cross flow heat exchanger with integral finned tube. International Journal of Scientific and Research Publications, 2016. 6(6).

6. Begum, B.A., et al., Identification of sources of fine and coarse particulate matter in Dhaka, Bangladesh. Aerosol and Air Quality Research, 2010: p. 345-353.

7. Owen, M.K., D.S. Ensor, and L.E. Sparks, Airborne particles sizes and sources found in indoor air. Atmospheric Environment, 2003: p. 2149-2162.

8. Hoff, J.C., The relationship of turbidity to disinfection of potable water, in Evaluation of the Microbiology Standards for Drinking Water. 2000, US Environmental Protection Agency: Washington D.C. p. 103-110.

9. Sparks, D.L., Advances in Agronomy, ed. D.L. Sparks. Vol. 68. 1999: Academic Press.

10. Color, taste, and odor problems in drinking water. 2011, DOH

11. Emsley, J., Nature's building blocks: an AZ guide to the elements. 2011: Oxford University Press. 